\title{
Dr Alexander Majkowski: A physician and Kashubian writer and poet
}

\author{
Anna Kotulska, Eugene J. Kucharz
}

\section{Introduction}

Kashubians known also as Kassubians (in Kashubian language: Kaszëbi) are the Slavonic ethnic group inhabiting the Eastern Pomerania in Poland. They speak the Kashubian language that is classified as the West Slavonic language belonging to the Lekhitic group of languages. Kashubians are the direct descendants of Pomeranians [1]. The Pomeranians came into the northern part of Poland about the 5th century AC. The region they lived is now known as Pomerania. The oldest mention of the region's name is a seal of prince Barnin the First of Pomerania from the 13th century. The primary region inhabited by Pomeranians was located close to the Parsenta River that was the border separating them from the region inhabited by Veletians. Most of the Pomeranians lost their ethnic

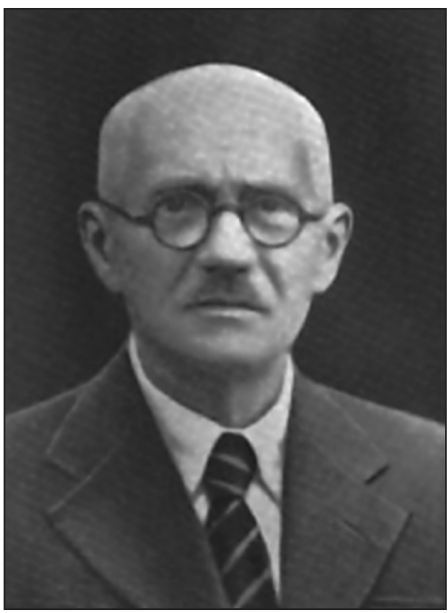

Dr Alexander Majkowski. Photograph from the last years of life identity when Pomerania became a part of Germany and the inhabitants were subjected to extensive Germanization. Those who were living in the Eastern Pomerania survived denationalization efforts of the German state. Now in the Eastern Pomerania in Poland, over 300.000 people consider themselves as Kashubians. Some estimation indicates for higher number of Kashubians, i. e. 500.000. Part of them declares Polish nationality. In 19th and 20th century, Poland and Poles even when there was no independent Polish state significantly supported actions 
for saving ethnic identity of the Kashubians (e. g. during so-called the Pan-Slavic Congresses i. e. periodic meetings of representatives of all Slavonic nations). Thus, the historical ties with Poles among Kashubians are very strong, and all are practically bilingual. Small groups of Kashubians are living abroad, including the United States.

Currently, the Kashubians are living in the region that is located within the geographical boarders of the city of Gdańsk (German: Danzig) on the East side, cities of Słupsk and Ustka from the West, the Baltic Sea coast from the North and city of Chojnice from the South. The main city (not the biggest one) of the region is Kościerzyna, considered as "a Kashubian capital". In past the main occupation of Kashubian was fishing, now mainly tourism. The region contains a number of picturesque lakes, the Szymborskie hills with the highest point $328 \mathrm{~m}$ over see level (the Wierzyca mountain). Part of the region is a seaside and part is the Darzlubska forest.

The oldest known literary work in Kashubian is dated from 1402 [2]. The common written language developed much later. Its orthographic and grammar rules were elaborated by a physician, Dr Florian Ceynowa (1817-1881) [3]. He is considered as "a father of Kashubian literature". In 1843, he published the first modern works in Kashubian including "Wiliô Nowégo Rokù" ("A New Year Eve"). In a short time, his activity was followed by many others. The greatest man of letters representing the literary movement known as "Młodokaszubi" ("The Young Kashubians") is Dr Alexander Majkowski who was working all his life as a physician. The aim of the study is to present life and achievements of the forgotten Dr Alexander Majkowski who contributed so much to the Kashubian literature.

\section{Life of Alexander Majkowski}

Alexander John Alois (the Polish spelling of the given names: Aleksander Jan Alojzy) Majkowski was born on July 17, 1876 in Kościerzyna (German name: Berent), an informal capital of the Kashubian region [4]. He was a son of farmers: John Anthony Majkowski (1844-1913) and his wife Josephine Augustine Majkowska née Bask (1858-1937). His family belongs to so-called gburs i. e. a group of rich farmers of the region. The Majkowski's parents were living in the city of Kościerzyna but they were born in the surrounding villages. The father was born in Zdunowice (German name: Zdunowitz) and the mother in Lubiana near Kościerzyna. The parents were Roman Catholics [5]. It is of interest that the Majkowski's parents were farmers and also they were resided in the city. These farmers had their farms outside the central part of the city but still within the city borders. They were officially called "municipal farmers" (German name: Akkerbürger). Alexander Majkowski was the oldest child of the family. He had two brothers (Anthony - 1880-1944, and August - 1884-1925) and two sisters (Francisca - 1882-1967, and Helen, married Radtkowa - 1893-?). The data on life of the Alexander's siblings are scanty. It seems that he was the only child who received 
education. When Alexander was 6-year old according to German regulations, he began education in the primary school. He attended the Catholic primary school in Kościerzyna and latter he attended the German high school in Chojnice (German name: Konitz). In this time, the region was a part of Prussia and the only language of instruction in schools were German. In primary school Polish language was instructed as additional language and was considered as the foreign language. The high school in Chojnice was famous, and two other famous Kashubian writers (Florian Ceynowa and Hieronime Derdowski) were earlier its graduates. During the high school years, Majkowski was a member of "The Mickiewicz Society" an illegal Polish association of high school students. The

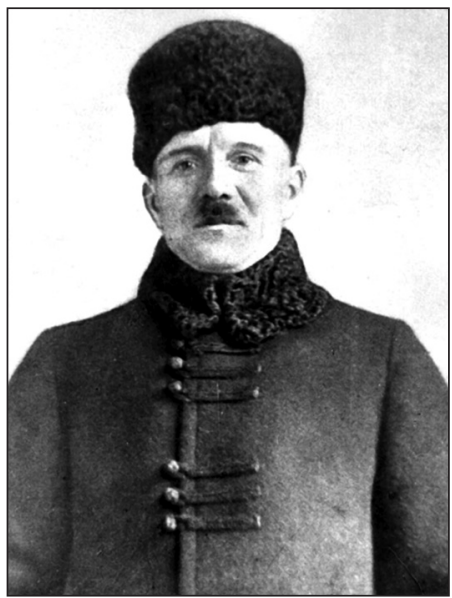

Dr Alexander Majkowski wearing a national Kashubian costiume association was not registered and approved by the school authorities but was tolerated despite its illegal status. The main goal of the Mickiewicz Society was reading of Polish literature, and the name of the organization was derived from the name of the greatest Polish poet, Adam Mickiewicz. Alexander Majkowski graduated the high school in 1895 and received so-called "Maturität" (an official certificate of passing of the final high school exams) [6]. The family, especially mother expected that Alexander would continue his education to be a priest. He did not feel the call. After high school graduation due to financial problems, Majkowski was unable to continue further education at once. He went to a village, Lamka and stayed with his uncle. In this small village, located between Chojnice and Kościerzyna on the river Młosina, he wrote his first known literary work in Kashubian language, "Jak w Koscérznie koscelnégo obrelë abo piec kawalerów a jednô jedynô brutka. W osem spiewach" (see later). Alexander Majkowski living in Lamka was giving tutoring to high school students and was collecting in this way financial means to begin his further education. Next spring, in April 1877, he was admitted to the Medical School at the Berlin University [7]. Majkowski was registered at the university on April 30, 1897 and matriculation document was dated May 4, 1897 [8]. His further education was facilitated by a scholarship given by the Kashubian-Polish association "Mutual Assistance" in Chełmno. He was also received financial support from his parents. The correspondence with his parents from that period preserved, and confirmed his strongly Polish attitude. All letters were written in a very correct Polish language. During the medical studies in Berlin, Majkowski began to write to the Polish journals, including "Dziennik 
Berliński" ("The Berlin Daily") that appeared in Berlin for Polish community of this city as well as "Gazeta Gdańska" ("The Gdańsk Journal") that was published in Gdańsk. Thank to support of Bernard Zygmunt Milski, the editor of chief of the last journal, Majkowski was sent to Warszaw to take part in ceremony of unveiling of the monument of a great Polish poet Adam Mickiewicz. It was a great moment in life of further man of letters. He met during the unveiling ceremony a number of Polish writers and poets, some of them become his friends (e. g. John Alexander Karłowicz, John Kasprowicz) [9].

In 1900, Alexander Majkowski moved to the University of Greifswald to continue his medical education. This was an old university founded by the Pomeranian prince Wartislaw. Many of the students were Poles, and several Polish student organizations were active at the university [10]. Majkowski was co-founder and was elected one of the leaders of the Polish Student Association "Adelphia" [11]. He was involved in teaching Polish language, history and literature to Polish farmers working as casual laborers in big German farms. The university authorities discovered this activity and Alexander Majkowski was rejected from the university on 26 February 1901 "wegen polnischer Agitation und Propaganda" ("for Polish agitation and propaganda") [12]. The Berlin University refused to accept him as a student, and Majkowski went to Munich where from the end of 1901, he continued medical studies. In Munich, Alexander Majkowski also participated in life of Polish associations. He was a member of "Vistula", the Association of Polish speaking students mostly from Pomerania. Majkowski graduated in 1903 in Munich and went to Zürich to prepare his doctoral thesis. He wrote the thesis entitled "Zur Frage nach der klinischen Bedeutung der punktieren Erythrozyten bei chronischen Saturnismus" ("The Problem of clinical application of punctuated red cells in patients with chronic lad intoxication") [13]. The thesis was approved in Munich in 1904. He passed the doctoral examination with honors on September 21,1904 . The thesis was prepared under supervision of Professor Johannes Rückert from Munich.

After graduation, Alexander Majkowski returned to his native land, and he became an assistant at the Saint Mary Hospital in Gdańsk (St. Marien-Krankenhaus). The hospital was a property of the Catholic Order of Sisters of Mercy of Saint Vincent a Paulo [14]. He completed his internship in November 1905, and moved to his native city, Kościerzyna where he opened his medical study. For a short time before he went to Kościerzyna, Majkowski substituted Dr Klimkowski in Jarocin, a city in Wielkopolska (the Poznań region). He was a general practitioner and his medical activity included surgery and obstetrics. In a short time, Majkowski became a popular physician of the region [15]. Majkowski was the second Polish physician in Kościerzyna. The first one was his friend Dr John Pellowski.

Dr Majkowski moved in 1910 to Sopot (German name: Zoppot). He continued his medical practice and was active in the Kashubian movement. Four year latter, during the First World War he was a military physician. He was working in the 
hospital in Chełmno (German name: Culm) and later in hospital in Pilawa (German name: Pillau). The battalion that Dr Majkowski was the military physician went up the line in the end of August 1916. The unit moved to Königsberg, later to Kraków, Lwów (German name: Lemberg) and to Romania. In Romania, Dr Majkowski on the horseback traveled with the unit more than $1400 \mathrm{~km}$. In autumn 1917, he was sent to the Western front. After a short visit to Sopot, he went to France [16]. In July 1918, Dr Majkowski due to health problems was sent to Metz and later to Sopot for better recovery. After the war, he was living in Sopot and was working in the International Committee for Establishment of the Boarders. There he had met his future wife, Alexandra Komorowska, who was interpreter at the Committee.

Dr Majkowski married Alexandra Komorowska. Their wedding took place in Warszaw on October 6, 1921. Alexandra Komorowska was born on December 27, 1891, although there are some controversies concerning her date of birth [17]. She survived her husband for 44 years, and she died on February 15, 1982 in the home for the aged in Wejherowo. The wife of Dr Majkowski was a subject of some legends and after the dead of Dr Majkowski, she did never showed in public and she did not participated in any commemorative ceremonies connected with her husband. Alexandra Komorowska was a descendant of landowner family. Her father was the owner of the estate in Bronisze (German: Wittichsfelde or Wittigsfelde) located in the Kashubian region. Later they sold the estate and moved to Sopot, and there in 1919 Alexandra met her further husband. She got education in Switzerland (Vinzel near lake Leman). The mystery of Alexandra was her first marriage. She married the count Roman Starzyński. They divorced and he changed religion to Lutheran in order to remarry. In that time, the divorce was not accepted socially and she distributed the rumor that her first husband was lost during the First World War. After the marriage in Warszaw, Dr Majkowski and his wife moved to Kartuzy, a city in the Kashubian region. They bought a house called "Villa Erem". There Dr Majkowski lived to the last days of his live. The widow with daughters lived there until 1964. Later she moved with two daughters to Gdańsk [18].

Dr Majkowski and his wife had four children. They received the given names of the Pomeranian prince family of the 13th-14th century. The oldest was daughter Damroka Pelagia (August 14, 1922-August 6, 1979 in Gdańsk). The only son Mestwin Alexander was born on April 28, 1924. He was drafted during the Second World War to the German army and was killed at the Eastern front on July 20, 1944. Two remaining children were daughters, Barbara Josephine (October 1928-June 25, 1983 in Kartuzy) and Witoslawa Christina (December 25, 1929-September 29, 1955 in Gdańsk). The daughters were unmarried and died without leaving grandchildren to Dr Majkowski. The son also did not left descendants [19].

In the last years of his live Dr Majkowski was more active in literature than medicine. His practice became less and less popular, and the family had financial 
problems. One of the reason of the financial difficulties, as remembered by the contemporary inhabitants of Kartuzy was life style of the wife who had been used to live in rich home, full of servants and with a broad social life. The income of the physician-writer, who offered more time to literature than to the patients, was too low to maintain the family. It is possible that he was overusing alcohol however there is no any proof of his alcoholism.

Majkowski died in Gdynia on February 10, 1938, and was buried at the Kartuzy cemetery [20]. The funeral became a great Polish patriotic manifestation.

\section{Literary and Organizational Achievements of Majkowski}

Still a student, Alexander Majkowski was an active journalist. He wrote several essays that were published in "Gazeta Gdańska" and "Dziennik Berlinski". In 1899, he published a short satirical novel entitled "Jak w Koscérznie koscelnégo obrelë abo piec kawalerów a jednô jedynô brutka. W osem spiewach" ("How in the city of Kościerzyna sacristan was swindled or five bachelors and one girl. In eight parts") [21]. The novel was written in Kashubian. Alexander Majkowski published the first Kashubian collection of poems in 1904 (the date on the title page is 1905). The collection was entitled "Spiewe i frantówci" ("Songs and poems") [22]. The collection contains several poems that had been written in time of his studies. Hankering to his native land inspired some poems, the others describe beauty of the Kashubian region. There were also two Kashubian translations of the odes by Horatius.

During his internship in Gdańsk, Dr Majkowski once again established close cooperation with the journal "Gazeta Gdańska". He was also the editor-in-chief of the journal (March 1, 1905-July 20, 1905). Under his influence, the journal was especially interested in problems of Kashubians. He was an author of a few editorials, indicating Slavonic roots of the Kashubian language, culture as well as danger of Germanization. He was a founder of a supplement to "Gazeta Gdańska" published entirely in Kashubian. The supplement was entitled "Drużba. Pismo dlö polscich Kaszubów" ("The Friendship. A journal for Polish Kashubians") [23]. The motto of the supplement was "Nimo Kaszub bez Polonii a bez Kaszub Polści" ("There is no Kashubian region without Poland and there is no Poland without the Kashubian region"). "Drużba" was the first literary journal published in the Kashubian language. Six volumes of the supplement were published. They contained poems by Dr Majkowski as well as poems by Hieronim Derdowski and Franciszek Sędzicki and ethnographic works of Dr Florian Ceynowa. Although the supplement was not published for a long period, it became a beginning of journals published in Kashubian. Several later efforts to publish periodicals in Kashubian were resulted from activity of Dr Alexander Majkowski.

When Dr Majkowski established his medical practice in Kościerzyna, he did not discontinue his collaboration with "Gazeta Gdańska". Kościerzyna was a city located in Western Prussia inhabited mostly by Polish population. The Poles were 
subjected to extensive Germanization. Dr Majkowski published several papers to stimulate development of Polish business and trade. The popular idea was "Poles buy in shops owned by Poles". There were also two groups of Catholic school children prepared for the first communion; one of them received tutoring in Polish (about 50 children) and remaining in German (5-10 children) [24]. Due to Germanization efforts almost all children were pushed to learn religion in German. Dr Majkowski was a leader of spontaneous movement against the priest who supported Germanization and he had to leave the city. He was substituted by Rev. Bolesław Masłowski (1872-1928) who known Dr Majkowski from the high school time, both were graduated of the school in Chojnice. The Catholic Church in Kościerzyna was not more involved in Germanization. In February 1906, Dr Alexander Majkowski founded the Kościerzyna Division of the organization "Straż. Towarzystwo ku obronie spraw ekonomicznych i społecznych" ("The Guard, Society for Protection of Economic and Social Situation of Poles"). It was a Polish association founded in Poznań on April 25, 1905. The main goal of the society was stimulation and support to Poles in their fighting against the Germanization efforts. The organization used legal methods and stimulated economic development of Poles (shops, trade, craftsmen, etc.) as well as protected against selling the land into the German owners. The next significant effort of Dr Majkowski was foundation of the committee to build "the Polish House" in Kościerzyna [25]. Thank to his activity on September 17, 1906, the association "the Kashubian House" was founded. The executive board consisted of Rev. John Cichocki from Grabów, Teofil Czarnowski, treasurer and Dr Majkowski, a secretary. The association activity resulted in opening of the house finally called "Dom Kaszubski - Bazar" ("The Kashubian House - The Market"). There were housed "Czytelnia Polska" (The Polish Library with a reading hall) and later the editorial office of the journal "Gryf". In 1908, Dr Alexander Majkowski founded a new journal "Gryf" ("Griffon", a traditional coat of arm of Pomerania). It was a turning point in the history of the Kashubian movement. The journal became a main center attracting all activists, including writers and poets of so-called the Young Kashubians movement. The journal published several research studies on history, culture, ethnography etc of Kashubians as well as numerous literary works. "Gryf" was published from November 1908 to end of 1912. During all this period, Dr Alexander Majkowski supported the journal in several ways, including financing it from own means. He was also an author of numerous publications that appeared in "Gryf". His writings amounted for about 40 per cent of all text volume of the journal. The main goal of "Gryf" was to create knowledge and understanding of ethic identity of Kashubians and to indicate their ties with Poles and other Slavonic nations. On the other hand, "Gryf" did not included papers stimulating any military actions or direct separatist movement.

In 1909, Dr Majkowski organized the only in the Kashubian region solemn celebration of the centenary of birth of Juliusz Słowacki, the great Polish poet. The celebration took place in Kościerzyna. 
In 1910, Dr Majkowski moved to Sopot. There he opened his physician's study. In the same year, he attended the Pan-Slavonic Congress in Sofia (now: Bulgaria). One year later, the editorial office of "Gryf" moved to Gdańsk, a few miles from Sopot. Dr Majkowski collaborated with a layer, Dr Francis Kręcki (1883-1940) his junior colleague and dedicated activist of the Kashubian movement. Dr Kręcki was born in Borzestów but since his young years he lived in Kościerzyna. The German authorities refused him to open the advocate office thus he was working as a legal adviser in the Trade Company "Ceres" in Gdańsk. Under the co-editorship of Dr Kręcki "Gryf" once again became the regular periodical journal. The first issue of the new edition appeared in April 1911. In the same time, Dr Majkowski decided to establish the official association of the Young Kashubians. In 1912, he prepared the "Odezwa w sprawie założenia organizacji młodokaszubskiej" ("Proclamation on foundation of the Young Kashubian organization") signed by about 15 activists. The foundational congress take place in Gdańsk on June 20-21, 1912, and was attended by more than 60 participants, although the number of the registered individuals who had been interested in the participation has been higher, more than 100 . The congress founded the Young Kashubian Society and Dr Majkowski was elected the secretary general of the society. The society became mostly active in journalistic papers and literary works [26]. Later the society was considered as the main literary movement in the whole history of the Kashubians.

Dr Majkowski was also founder of the first Kashubian Museum in Sopot [27]. The aim of the Kashubian-Pomeranian Museum was presentation of the Kashubian art and traditions in the place visited by tourists from various countries, including Poles living in different parts of formerly independent Poland. The Museum was opened on July 1, 1913. The collection included pieces of the Kashubians' folk art, description of their history and temporary exposition of Asian folk art provided by Zaremba Belekowicz, a Polish born French consular officer. Purchasing and donations at the region obtained the main collection. The Museum was located at the main street of Sopot. In January 1914, the Museum opened a school of folk Kashubian embroidery. The Museum was closed with the outbreak of the war. The collection was places in the house of Majkowski and later was dispersed.

The outbreak of the First World War interrupted the activity of the Young Kashubian Society. Dr Majkowski was drafted to the German army and was the military physician. During the war, Majkowski was writing a diary. On the base of his notes he prepared his memoirs that were later published. During the military service he became sick and was sent for treatment to Metz and later to Sopot. The First World War was close to its end. In Germany, the revolutionary movement was very active; the workers and solders councils were founded all over the place, after the navy rebellion in Kiel. The workers and solders council in Gdańsk was founded on November 10, 1918, and was followed by the others of the region. 
Some Kashubians took part in the council. The revolutionary movement in Germany was associated with independence activity of Poles. Dr Majkowski took part in the Kashubian movement. In the some time, the Polish People's Councils were founded. Their aim was to rebuild independent Poland and to joint the border regions inhabited by Poles to the new established Polish state. On December 3, 1918, the Polish Regional Parliament met for the first time in Poznań. It consisted of representation of various regions inhabited by Poles, including Pomerania. Dr Majkowski was a delegate to the Parliament. In a short time, on December 27, 1918, the Wielkopolskie Insurrection broke out. The insurrection was arranged by Poles against Germany and was successful. The region of Wielkopolska became a part of Poland. A number of Kashubians took part in the insurrection. Dr Majkowski supported the insurrection in many his speeches. He was also a president of the Polish People's Council in Sopot. The Council became a field of conflict between different political groups, from very nationalistic oriented to radical workers' movement. The conflict resulted in resignation of Dr Majkowski from the post of the Council's president.

In spring 1919, the representatives of Pomerania were sent to Paris to present the documents of the Polish national orientation of the Pomeranian inhabitants. Dr Majkowski resigned from the post of the president and was not included in the delegation. The Kashubian representative took with them the volumes of "Gryf", a Kashubian journal edited by Dr Majkowski. Volumes of "Gryf" were included in documentation at the Versailles Conference as one of the proofs of Polish ties of the Kashubian region. During the Conference the borders within Europe were established after the First World War. In summer 1919, the Versailles Conference decided to add the Kashubian region to Poland, a country that regained independence after more that century.

Dr Majkowski was working in the International Committee for Establishment of the Boarders. Headquarters of the Committee were located in Poznan and had tree divisions: from Polish-German border, Polish-Czech border and Polish-Gdańsk border. The archive of the Committee did not survived but some documents are available. Dr Majkowski was working at the Office of the Polish Commissioner for Establishment of the Polish-German Border (Le Commissaire $d u$ Governement Polonais pour la fixation de la frontiere polono-allemande) as the vice-president and secretary of the Subcommittee for the Northern Border (SousCommission du Nord). The Subcommittee was located in Grudziądź [28].

Dr. Majkowski was also a member of the Committee for New Geographical Names in the region. The borders were finally established after the Polish-Bolshevik war with the Red Russia in 1920.

In January 1919, the Pomeranian Publishing House was established in Bydgoszcz, and in a short time moved to Gdańsk. There, the Polish journal "Dziennik Gdański" ("The Gdańsk Daily") was published. Dr Majkowski became the editor-in-chief of the newspaper. The first number of the daily appeared in print 


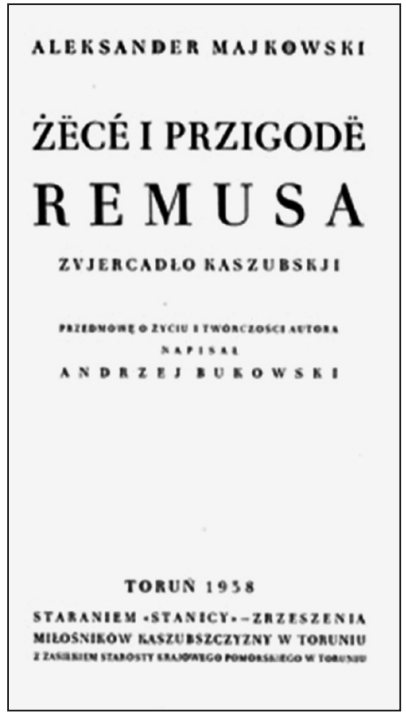

Title page of the Kashubian edition of "Z̈ëcé i przigodë Remusa" ("Life and adventures of Remus") on August 1, 1919. The newspaper was published until 1925. It seems that after two-three years the role of Dr Majkowski in the daily was not so significant as at the beginning. On July 17, 1919, Dr Majkowski was co-founder of the Democratic Circle (Koło Demokratyczne). The association was intended to be a group of intelligentsia oriented for development of democracy. The Democratic Circle associated representatives of various political groups. After a few months, the Democratic Circle became a part of the Joint Committee of Polish People's Associations.

The post-war situation of Pomerania was very complex. The first effort of its Kashubian inhabitants was free the region from German influence and to joint Pomerania to Poland. The next steps were associated with obtaining some autonomy and development of the Kashubian movement under peaceful conditions. This places the movement in quite new situation. It had to establish its own identity in free country. In past most of the activity was oriented against Germanization, the common goal united the Kashubians. The years 1923-1938 were the years of some stabilization of Pomerania. In free Poland, the region became the field of influence of several political forces. The Kashubian movement became more and more dispersed. A number of various Kashubian organizations were founded and they had different political orientation. Dr Majkowski from one side was considered as an eminent pioneer of the Kashubian movement from the other side he suffered that the idea of free region with some autonomy is a subject of political play of different groups that according to him used the Kashubian name to won own political profits [29]. More and more he was disheartened to the Kashubian movement and dedicated himself to literary work.

The most important literary work of Dr Majkowski is a novel "Z̈ëcé i przigodë Remusa" ("Life and adventures of Remus"). He was writing the novel probably for many years. From various letters to family and friends, it can be concluded that Dr Majkowski had began to wrote the novel in 1903 in Munich, than continued his work in Pilawa on summer 1916. The first chapters of the novel were published in "Gryf" in 1922. After publication of a small part the journal was discontinued. The complete first volume was published at the cost of author in 1935 [30]. The second volume appeared in print after the dead of the author in 1938. 
The title character of the novel, Remus is a Kashubian individual in same way the Kashubian Don Kichote. He is fictional person living in the second half of the 19th century and wandering from village to village in the region. His life is shown in the novel in the rich description of social and political atmosphere of Kashubians as well as with rich description of the beauty of nature and folk traditions. Remus is in many aspects an allegoric character. He is a hero of struggle for better future, many aspects of his adventures originated in fairy tales of the Kashubians. His main goal is the carry the princess to the fortress of happiness. In the same time, Remus is a character made with a deep psychological analysis and surrounded by very real Kashubian world.

The main literary work of Majkowski "Z̈ëcé i przigodë Remusa" was translated to Polish by Lech Bądkowski and published in 1964. It was a very controversial issue because the post-war regime in Poland did not recognize the Kashubian as a separate language and considered it as a dialect of Polish that cannot be translated. The discussions and comments were published and resulted in wider interest in the work of Dr Alexander Majkowski. The second edition appeared in 1966. In 1974, the original Kashubian text was reedited. Later, the bilingual edition was published (1995 [31], 1997 [32]). On the base of the first volume of the novel, the TV film was produced in 1987 [33]. Eva Brenner née Brauer (1911-1993), Lutheran pastor born in Kartuzy later living in Germany, translated the work to German [34]. French translation appeared in 1985 and was done by Jaqueline Dera-Fischer [35]. The translation has a new title "The pedlar of the stars". Also some verses by Majkowski were translated to German and appeared in various anthologies [36].

Two other works by Dr Majkowski should be mentioned. The first one is the "Historia Kaszubów" (The history of Kashubians). The scientific study on the history of his nation was written with a great narrative style. The book appeared in Gdynia in 1938 and was re-edited in 1991 [37]. English translation of the most famous book of Majkowski was published for the first time in 2008, and was done by Blanche Krbechek and Katarzyna Grolik-Luton [38].

The guidebook "Zdroje Raduni" ("The Springs of Radunia") that was published three times is considered as classical description of the region. The book was published for the first time in 1913 [39]. The next editions appeared in print in 1924 and in 1935. The book was one of the first or the first one published in Polish guidebook on the Kashubian region known as "The Kashubian Switzerland". The previous guidebooks were published only in German.

\section{Conclusion Remarks}

It is of interest that physicians together with priests were common among those who significantly contribute to development of culture and national identity of relative small national groups. It was resulted probably from their education and knowledge of languages, more frequent visits to other countries and some 
independence of the profession as well as high social and economic position. Such happens for example in Silesia (the southern region of Poland) where several activists were educated as physicians or priests [40]. The same phenomenon is found in the Kashubian region. The leading writers of both first and second generation of Kashubian writers and poets were physicians. It may be a part of more general social phenomenon, i. e. cultural contribution of physicians to development modern societies, especially small ethic groups.

Kashubian language is for years a subject of controversies. In time of Germanization, the authorities blocked using of the language. The publications appeared in Polish journals. Later between the First and Second World War, the Kashubian region was part of Poland and the language developed freely. In Communist Poland, Kashubian language was considered a dialect of Polish, and independent movement of Kashubians was not permitted. Since 1989, independent and free Poland allowed Kashubian to published and use their language within the region as well as several studies on literature and culture have been carried out.

In modern Europe, a new phenomenon became more and more visible. It is known as "small nation languages". These languages are spoken by a relatively small number of inhabitants, and in most cases their written works and rules are much younger than those of "big languages". As one of the criterion to distinguish "small language" from dialect is own translation of the Bible. Such translation exists in Kashubian. Now Kashubian is both a subject of several studies and is a language of instruction in a number of schools. The role of physician in development of literary works of so-called small languages in Europe needs further studies. The life and activity of Dr Alexander Majkowski seems to be a good example of the relatively unknown role of physicians in cultural development.

\section{Sources}

The primary sources on life and achievements of Dr Alexander Majkowski are dispersed in a number of archives. The main collection of manuscripts and several printed sources are preserved in the Literary and Music Museum of the Kashubian and Pomeranian Region (Muzeum Piśmiennictwa i Muzyki Kaszubsko-Pomorsk$i e j$ ) in Wejherowo (Poland) and the Archive of the Kashubian Museum (Archiwum Muzeum Kaszubskiego) in Kartuzy (Poland). Damroka Majkowska, a daughter of Dr Alexander Majkowski donated all his personal collection of manuscripts and documents to the Museum in Wejherowo. Smaller collections are in the Manuscript Division of the Main Library of the Gdańsk University (Sopot) and the Library of the Gdańsk Section of the Polish Academy of Sciences (Gdańsk). Single documents are to be found in various Polish and German archives (e. g.: Toruń, Bydgoszcz, Gdańsk, Poznan, Berlin, München, Greifswald, Halle).

The main monograph on Dr Alexander Majkowski was published in Polish by Józef Borzyszkowski in 2002 [41]. It is the most compressive study on Majkowski 
and his surrounding historical and literary environment as well as his heritage. The monograph contains also a detailed list of primary sources and bibliography of works on Majkowski. Earlier, Andrzej Bukowski who almost whole life devoted to the studies on the Kashubian culture published several studies on Majkowski [42]. His works, manuscripts and documents are preserved in the Main Library of the Gdańsk University in Sopot.

Preserved photographs of Dr Majkowski are listed in the paper published in "Pomerania" [43].

Bibliography of papers and books referring to Majkowski is long although almost all of them are focusing on single aspects of his life and activity, and some of them are relatively superficial. The only work on Majkowski as the physician is the paper of Kucharz published in 1986 [44]. All works on Majkowski are published in Polish. Some studies on Kashubian culture are published in German including papers on Majkowski [45], and except the introduction to the English translation of "Z̈ëcé i przigodë Remusa" ("Life and adventures of Remus"), there is no studies on Majkowski published in English.

\section{References}

1. Majkowski A. Historia Kaszubów [History of Kashubians]. Gdynia: 1938'; Gdańsk: $1991^{2}$.

2. Neureiter F. Historia literatury kaszubskiej [History of Kashubian literature]. Gdańsk: 1982.

3. Karnowski J. Dr Florian Ceynowa [Biography of Dr. Florian Ceynowa]. Gryf, 1921, nr 2, p. 56-62, nr 3, p. 65-84, nr 4, p. 103-118; 1922, nr 1, p. 8-20, nr 2, p. 44-56.

4. State Archiv of Gdańsk, The Municipial Books of Kościerzyna (nr 2030/7, vol. 1, p. 82), the birth certificate of Dr. Alexander Majkowski.

5. Borzyszkowski J. Aleksander Majkowski. Biografia historyczna [Alexander Majkowski: a historical biography]. Gdańsk-Wejherowo: 2002, p. 86.

6. Borzykowski J., op. cit., p. 111.

7. Kusztelak G. Polacy na studiach lekarskich w Berlinie (1810-1918) [Poles, the university students in Berlin, 1810-1918].//Archiwum Historii Medycyny, 1972, vol. 35, p. 1-153.

8. University Archive of Berlin, cited after Borzyszkowski J. Aleksander Majkowski, p. 126.

9. Bukowski A. Majkowski, Aleksander [biographical note]. Polski Słownik Biograficzny, vol. 19, nr 1 (80), p. 199-202, Wrocław: 1974.

10. Borzyszkowski J. Meklemburgia i Pomorze Przednie w kulturze i tradycji ruchu kaszubsko-pomorskiego [Meklemburg region and Pomerania in tradition of the Kashubian movement]. Pomerania, 1998, nr 9, p. 10-13.

11. Wierzchosławski S. Polskie organizacje studenckie na uniwersytecie w Gryfii w drugiej połowie XIX i początkach XX wieku [Polish student 
associations at the Greifswald University in the second half of the 19th and beginning of the 20th century].//Studia Historica Slavo-Germanica, 1981, vol. 10, p. 56.

12. Bukowski A. Regionalizm kaszubski [The Kashubian regionalism]. Poznań: 1950, p. 127.

13. Majkowski A. Zur Frage nach der klinische Bedeutung der punktieren Erythrozyten bei chronischen Saturnismus [Doctoral thesis]. München: C. Wolf \& Sohns, 1904, p. 1-23.

14. Lüdtke C. Das St. Marien-Krankenhaus in Danzig. Zum 50 jährigen Jubiläum dieser Kranken- und Maisenanstalt am 13. November 1902 in dankbarer Erinnerung gewidmet von Dr. Lüdtke. [The St. Mary Hospital in Gdańsk (Danzig). On the 50th jubilee of the hospital with thanks to Dr. Lüdtke]. Danzig: 1902.

15. Kucharz E. J. Dr Aleksander Majkowski - lekarz i pisarz. [Dr. Alexander Majkowski, physician and writer]. Wiadomości Lekarskie, 1986, vol. 39, nr 10, p. 713-719.

16. Majkowski A. Pamiętnik $z$ wojny europejskiej roku 1914 [Memoirs of the European war 1914]. Edited from the manuscript by T. Linker. Wejherowo-Pelplin: 2000.

17. In the passport of Alexandra issued in 1918, the year of her birth was written as 1892.

18. Borzyszkowski J., op cit., p. 531.

19. Borzyszkowski J., op cit., p. 773.

20. Bukowski A. Pogrzeb dra Aleksandra Majkowskiego [The funeral of Dr. Alexander Majkowski]. Teka Pomorska, 1938, nr 1-2, p. 73-74.

21. Majkowski A. Jak w Koscérznie koscelnégo obrelë abo piec kawalerów a jednô jedynô brutka. W osem spiewach. Gdańsk: 1899.

22. Majkowski A. Spiewe i frantówci. Poznań $1905^{1}$ [printed by the author]; Gdynia $1957^{2}$ [edited by L. Roppel].

23. Drużba. Pismo dlö polscich Kaszubów. Gdańsk 6 May 1905. Supplement to Gazeta Gdańska [The Gdańsk Newspaper].

24. Kulczycki J. Strajki szkolne w zaborze pruskim 1901-1910. Walka o dwujezzyczna oświate [Protests of the school students in the Poland occupied by Prussia 1901-1910. The fight for bilingual education]. Poznań: 1993.

25. Kamiński A. "Dom Kaszubski" w Kościerzynie [The Kashubian House in Koscierzyna]. Kaszebë, 1958, nr 16, p. 4.

26. Bukowski A. Oblicze społeczne twórcy ruchu młodokaszubskiego [Social activity of the creator of the Young Kashubian movement]. Przeglad Zachodni, 1950, nr 5-6, p. 435-451.

27. Majkowski A. Muzeum Kaszubsko-Pomorskie [The Kashubian-Pomeranian Museum]. Świat, 1914, nr 11; Sprawozdanie Muzeum kaszubsko- 
pomorskiego w Sopocie za rok 1913 [Report of the Kashubian-Pomeranian Museum in Sopot, the year 1913]. Gdańsk: 1914; Romanow A. Sopot w latach 1818-1920 [Sopot in years 1818-1920].//Dzieje Sopotu do 1945 roku [History of Sopot before 1945]. Ed. B. Śliwiński. Gdańsk: 1998.

28. Borzyszkowski J., op.cit., p. 472.

29. Majkowski A. Młodokaszëbji. [The Young Kashubians]. Zrzesz Kaszëbskô, 1938, nr 12; Majkowski A. Wspomnienia moje [My memoirs]. Teka Pomorska, 1938, nr 5-6 and Pomorze, 1988, nr 1.

30. There are a few mistakes connected with the date of printing of the first volume of the novel. The date printed on the title page is "1930". The explanation is as the following: Dr. Majkowski began to print the novel in the Printing House of Adolph Splitt in Kartuzy in 1930. After printing a few pages the printing house bankrupted and the already printed pages were collected by the author. Later, the same Adolph Splitt in 1933 once again opened a new printing house and set up the next pages. He died suddenly before finishing the work. The remaining part of the book was printed by John Bielinski, the owner of the "Gazeta Kartuska" ("The Kartuzy Newspaper") using the previously typesetted and printed pages.

31. Majkowski A. Żëcé i przigodë Remusa. Życie i przygody Remusa. Przekład L. Bądkowski [translation by L. Bądkowski]. Gdynia: Arkun, 1995.

32. Re-edition of the Polish translation and the original Kashubian text in two separate volumes. Gdynia: Arkun, 1997.

33. Kowalski J. "Remus" w telewizji ["Remus" in television]. Pomerania, 1987, nr 9, p. 24-25.

34. Majkowski A. Das abenteuerliche Leben des Remus.//Schriften des Komittees zur Förderung der Slavischen Studien, vol. 10/I. Köln-Wien: Böhlau Verlag, 1988.

35. Majkowski A. Le colporteur aux etoiles. Parut: RTL Edition, 1985.

36. Neureiter F. Kaschubische Anthologie [The Kashubian Anthology]. München: 1973.

37. Majkowski A. Historia kaszubów [A history of Kashubians]. Gdynia: $1938^{1}, 1991^{2}$.

38. Kajkowski A. Life and adventures of Remus. English translation by B. Krbechek and K. Grolik. Luton, Gdańsk: 2008.

39. Majkowski A. Zdroje Raduni [The Springs of Radunia]. Warszawa, 1913', Warszawa: Polskie Towarzystwo Krajoznawcze, 1924², Kartuzy: Wydział Powiatowy, $1933^{3}$.

40. Brożek K. Z dziejów grupy zawodowej lekarzy na Górnym Śląsku [History of physicians as the professional group in the Upper Silesia].//Archiwum Historii Medycyny. 1974, vol. 37, nr 4, p. 425-237.

41. Borzyszkowski J. Aleksander Majkowski. See ref. 5

42. The most valuable publication of Andrzej Bukowski on Dr. Majkowski 
are: Aleksander Majkowski.//Bibliografia literatury polskiej. Nowy Korbut [The New Korbut's Bibliography of the Polish Literature], vol. 15. Warszawa: 1977; Aleksander Majkowski. Literatura polska. Przewodnik encyklopedyczny [The Polish Literature, an encyclopedia]. vol. 1. Warszawa: 1984; Folkloryści kaszubscy XVIII, XIX i XX w. [Folklorists of Kashubians in the 18th, 19th and 20th century]. Literatura ludowa, 1959, nr 1-2; Najnowsza literature kaszubska [Recent literary works of Kashubians]. Wiadmości literackie, 1937, nr 27; Życie i twórczość Aleksandra Majkowskiego [Life and works of Alexander Majkowski].// Introduction to A. Majkowski Z̈ëcé i przigodë Remusa. Toruń: 1939.

43. [Anonimus] Aleksander Majkowski w fotografii [Photographs of Alexander Majkowski]. Pomerania, 1988, nr 2.

44. Kucharz E.J., see ref. 15.

45. Neureiter F., see ref. 36.

\section{Summary}

Dr Alexander Majkowski, a physician, writer and poet is the most famous creator of literature in the Kashubian language. Kashubians are the Slavonic group inhabiting the Eastern Pomerania in Northern Poland. Dr Alexander Majkowski was born on July 17, 1876 in Kościerzyna. He studied medicine in Berlin, Greifswald and Munich. After graduation, he worked in Gdańsk (Danzig), Kościerzyna and Sopot. During the First World War, he was a military physician and after the war lived in Kartuzy. Dr Majkowski died in Gdynia on February 10, 1938.

Since early years of the university studies, Dr Majkowski published poems and novels in Kashubian as well as a number of journal articles. He was founder of so-called the Young Kashubian movement, and one of the leading persons in the movement for national and ethnic identity of Kashubians. He was founder and editor of the journal "Gryf", the main journal of Kashubians. The novel "Z̈ëcé i przigodë Remusa" ("Life and adventures of Remus") is the highest achievements of the Kashubian literature and is an important part of their cultural heritage. The novel was translated to Polish, German and French.

Authors' address:

Department of Internal Medicine and Rheumatology,

Medical University of Silesia,

ul. Ziołowa 45/47, PL 40-635 Katowice, Poland

fax: +48-32-2029933,

e-mail (E. J. Kucharz): ejkucharz@poczta.onet.pl

(Corresponding author: Eugene J. Kucharz) 